\title{
GENERALIZATION OF HILBERT AND HARDY-HILBERT INTEGRAL INEQUALITIES
}

\author{
YANG Bicheng, Ilko BRnetić, MARIO KRnić AND Josip PeČARIĆ
}

\begin{abstract}
The main objective of this paper is a study of some new generalizations of Hilbert's and Hardy-Hilbert's type inequalities. We establish general form of multiple Hilbert-type inequality and we also introduce multiple inequality of Hardy-Hilbert type. Further, the best possible constants are obtained for some general cases.
\end{abstract}

Mathematics subject classification (2000): 26D15.

Key words and phrases: Inequalities, multiple Hilbert's inequality, multiple Hardy-Hilbert's inequality, beta function, gamma function, equivalent inequalities, best possible constant.

\section{REFERENCES}

[1] M. Abramowitz AND I. A. STEGUn, Handbook of mathematical function with formulae, graphs and mathematical tables, National Bureau of Standards, Applied Math. Series 55, 4th printing, Washington 1965.

[2] Y. BICHENG AND T. M. RASSIAS, On the way of Weight Coefficients and Research for the Hilbert-type inequalities, Math.Inequal. \& Appl., 6, 4 (2003), 625-658.

[3] Y. Bicheng And G. MingZHe, On a Best Value of Hardy-Hilbert's Inequality, Advances in Math. 262 (1997), 159-164.

[4] Y. BICHENG, On Hilbert's Integral Inequality, J.Math.Anal.Appl. 220 (1998), 778-785.

[5] Y. BICHENG, On a General Hardy-Hilbert's Integral Inequality with a Best Value, Chinese Annals of Math. 21A 4 (2000), 401-408.

[6] Y. BICHENG, On Hardy-Hilbert's Integral Inequality, J.Math.Anal.Appl. 261 (2001), 295-306.

[7] Y. Bicheng, On a Multiple Hardy-Hilbert's Integral Inequality, Chinese Annals of Math. 24A 6 (2003).

[8] I. BRNETIĆ AND J. PEČARIĆ, Generalisation of Hilbert's Integral Inequality, Math.Inequal. \& Appl. 7, 2 (2004), 199-205.

[9] I. BRnETIĆ AND J. PEČARIĆ, Generalization of Inequalities of Hardy-Hilbert's type, Math.Inequal. \& Appl. 7, 2 (2004), 217-225.

[10] G. H. HARDY, Note on a Theorem of Hilbert Concerning Series of Positive Terms, Proc. London Math. Soc, 23, 2 (1925), Records of Proc. XLV-XLVI.

[11] G. H. Hardy, J. E. LitTlewood AND G. PólYA, Inequalities, Cambridge Univ.Press, Cambridge 1952.

[12] K. Jichang, Applied Inequalities, Hunan Education Press, Changsha, 1993.

[13] M. KRnić AND J. PeČARIĆ, Hilbert's Inequalities and theirs Reversions, Publ. Math. Debrecen (submitted).

[14] M. KRNIĆ AND J. PeČARIĆ, General Hilbert's and Hardy's Inequalities, Math. Inequal. \& Appl., 8, 1 (2005), 29-51.

[15] M. KRnić, G. MingZHe, J. PeČArIĆ And G. XuemeI, On the best constant in Hilbert's inequality, Math. Inequal. \& Appl., 8, 2 (2005), 317-329.

[16] A. KufNer AND L.-E. Persson, Weighted Inequalities of Hardy type, World Scientific, Publishing Co. Singapore/New Jersey/London/Hong Kong, 2003.

[17] H. LEPING, Y. JiAngMING AND G. MINGZHE, An Extension of Hilbert's Integral Inequality, J.Shaoguan Univ. (Natural Science), 23, 3 (2002), 25-30. 
[18] G. Mingzhe And Y. Bicheng, On the Extended Hilbert's Inequality, Proc.Amer.Math.Soc, 126, 3 (1998), 751-759.

[19] D. S. Mitrinović, J. E. PEČARIĆ AND A. M. FInK, Inequalities involving functions and their integrals and derivatives, Kluwer Academic, Boston, 1991.

[20] H. Yong, All-sided Generalization about Hardy-Hilbert Integral Inequalities, Acta Math. Sinica, 44, 4 (2001), 619-626.

[21] W. ZhuXI And G. Dunrin, An Introduction to Special Functions, Science Press, Beijing, 1979. 